\title{
THE PREVALENCE OF UNWANTED SEXUAL EXPERIENCES AMONG BELGIAN AND SOUTH AFRICAN STUDENTS
}

\section{A Revell, A Vansteenwegen, L Nicholas}

\section{INTRODUCTION}

Child sexual abuse (CSA) is a global problem and South Africa has been identified as a highCSA incidence country (Jewkes, 2002; Meier, 2002; New York Times, 2002 cited in Women's International Network, 2002). Belgium is a low-CSA incidence country (Finkelhor, 1994) and the comparison of two similar populations from these countries would elucidate differences in unwanted sexual experiences of these two settings, reflecting social and cultural variables that may affect the problem. Back, Jackson, Fitzgerald, Shaffer, Salstrom and Osman (2003), contend that very few studies have compared individuals of different nationalities and also those residing in their own countries, which limits the understanding of potential cultural differences regarding CSA. In their study of 65 North American and 88 Singaporean women college students they found $15,4 \%$ of North American respondents had been exposed to CSA compared to $4,5 \%$ of Singaporean respondents, the majority of whom did not consider themselves as being abused. Miller, Johnson and Johnson (1991) contend that self-report biases and definitional problems permeate CSA research and they developed an Early Sexual Experience Checklist (ESEC) which seeks to avoid such problems. They argued that, because the ESEC assesses an explicit variety of non-coital responses and provides a non-restrictive response format, a high incidence of unwanted sexual experiences may be reported as is the case in their study.

Kendal-Tackett, William and Finkelhor (1993) in their review of 45 CSA studies also highlighted the need to improve and refine measures of the impact of CSA. They contend that the issue of seemingly asymptomatic children who have experienced CSA may reflect the limitations of the instruments used. Finkelhor (1994:413) advocated that methodologies and instruments should be selected with international comparison in mind and they stated that "more international comparative research about sexual abuse is badly needed". He found in his survey of 21 countries, including 10 national probability samples, that CSA rates ranged from $7 \%-36 \%$ for women and from 3\% - 29\% for men. Most studies found the CSA rate for women to be one and a half to three times the rate for men.

An Australian national probability survey of 1,793 participants found a CSA rate of 35\% for women and 16\% for men (Najman, Dunne, Purdie, Boyle \& Coxeter, 2005). They reported that CSA exposure had a higher impact on the sexual functioning of women than on men. They also reported that in the study the majority of men and half of the women reporting sexual dysfunction had not experienced CSA. Rind, Tromovitch and Bauserman (1998) found in a meta-analysis of 59 studies comprising 15,000 college students that relations between a selfreported history of CSA and sexual adjustment were low and it were even lower in magnitude when CSA was deemed to be consensual, but only in men.

Madu (2001) found a CSA incidence rate of 21,7\% for men and 23,7\% for women in his sample of 722 South African undergraduate psychology students, most of whom perceived themselves not to have been abused (83\% of men and 68,2\% of women). Collings (1997) reported a CSA incidence of $34,8 \%$ in a sample of 640 South African women. Madu and Peltzer (2000) reported a 54,2\% prevalence rate of CSA among 414 high school students (56\% males and 53,2\% females). Miller et al. (1991) surveyed 345 college students and found that 
192

$44 \%$ of respondents reported unwanted sexual experiences before the age 16 (49\% women and $38 \%$ men). Given the extent of the problem of CSA in South Africa and the need for international studies (Finkelhor, 1994) on this topic, this study therefore compared Belgian and South African students' unwanted sexual experiences. The aim of this study was to provide new information on the scope of unwanted sexual experiences in Belgium and in South Africa to increase public awareness. It further aimed to provide additional insights into international research into cultural similarities and differences in the occurrence of unwanted sexual experience.

\section{METHOD}

\section{Participants}

Participants in this present study were 1,081 South African and 2,608 Belgian first-year university students. Of the South African students, $736(68,8 \%)$ were women (mean age = $19,6, \mathrm{SD}=4.10)$ and $333(31,2 \%)$ were men (mean age $=19,3, \mathrm{SD}=3,40)$. Of the 2,608 Belgians, $60,9 \%(1,587)$ were women (mean age $=18,2, \mathrm{SD}=0,96)$ and $39,1 \%(1,017)$ were men (mean age $=18,3, \mathrm{SD}=1,63)$.

\section{Procedure}

During the first-year orientation programme at a specific South African and a specific Belgian university, students were advised that the accurate completion of the checklist was important for determining better counselling services to students. Approval for the research was obtained from the Human Ethics Committee of both universities. First-year university students completed the structured checklist under the supervision of senior counsellors. The student participants were also encouraged to consult counsellors about the issues raised in the checklist as well as any other matters of concern, as some students might have negative emotional reactions after the recall of their unwanted sexual experience. The checklist administered to the South African students was in English, while a Dutch translation was given to the Belgian students. The participants received a standard introduction and instructions on how to complete the checklist. All responses were confidential and participation was voluntary and anonymous. Participants were advised that they could withdraw from the study at any time.

\section{Instrument}

The Early Sexual Experience Checklist (Miller \& Johnson, 1998 cited Davis, Yarber, Bauserman, Schreer \& Davis, 1998) was used in this study. The ESEC consists of nine items that list explicit sexual behaviors and two additional items that allow respondents either to describe a further sexual event or to select "none of the above". The checklist includes (a) respondent's age, (b) respondent's age at the time of the most bothersome event, (c) age and (d) identity of the other person involved, (e) frequency and duration of the most bothersome experience, and (f) presence and type of any coercion. Items using a Likert-style format (1 (not at all) to 7 (extremely) also obtain various ratings of the most bothersome event (e.g., "How much did it bother you then?" "How much does it bother you now?"). Participants were informed to select any sexual behaviours that were unwanted and occurred before the age of 16 , and they had to indicate the experience that bothered/bothers them most at the time when it occurred and at the time of completing the checklist. Miller and Johnson (1998) found a onemonth test retest reliability of ,92, for the ESEC, using Cohen's kappa (cited Davis et al., 1998). 


\section{RESULTS}

When grouping unwanted sexual experience into categories such as less severe (exhibitionism, touching and fondling of sexual organs) and more severe (oral-genital contact, vaginal intercourse and anal intercourse), it is clear that four times as many South Africans as Belgians reported more severe unwanted sexual experiences $(15,8 \%$ vs $4 \%)$. Of the total sample, $12,3 \%$ of women and $8,5 \%$ of men indicated they had had an unwanted childhood sexual experience.

\section{TABLE 1 \\ THE TYPE OF INCIDENT THAT TOOK PLACE BEFORE THE AGE OF 16}

\begin{tabular}{|c|c|c|c|}
\hline $\begin{array}{l}\text { Another person showed his or } \\
\text { her sex organs to you * }\end{array}$ & $\begin{array}{c}\text { Belgium } \\
\mathrm{n}(\%) \\
\mathrm{n}=253 \\
(74,2 \%)\end{array}$ & $\begin{array}{c}\text { South Africa } \\
\begin{array}{c}n(\%) \\
n=256 \\
(66,2 \%)\end{array}\end{array}$ & $\begin{array}{c}\chi^{2} \\
\chi^{2}=5,603, \mathrm{df}=1, \mathrm{p}< \\
0,05\end{array}$ \\
\hline $\begin{array}{l}\text { You showed your sex organs to } \\
\text { another at his/her request }\end{array}$ & $\begin{array}{l}\mathrm{n}=102 \\
(31,1 \%)\end{array}$ & $\begin{array}{c}\mathrm{n}=95 \\
(26,3 \%)\end{array}$ & $\begin{array}{c}\chi^{2}=1,925, \mathrm{df} \\
0.05\end{array}$ \\
\hline $\begin{array}{l}\text { Someone touched or fondled } \\
\text { your sex organs } *\end{array}$ & $\begin{array}{l}\mathrm{n}=172 \\
(51,3 \%)\end{array}$ & $\begin{array}{l}\mathrm{n}=227 \\
(59,9 \%)\end{array}$ & $\begin{array}{c}\chi^{2}=5,274, \mathrm{df}=1, \mathrm{p}< \\
0,05\end{array}$ \\
\hline $\begin{array}{l}\text { You touched or fondled } \\
\text { another person's sex organs at } \\
\text { his/her request } *\end{array}$ & $\begin{array}{l}\mathrm{n}=123 \\
(36,9 \%)\end{array}$ & $\begin{array}{c}\mathrm{n}=193 \\
(52,2 \%)\end{array}$ & $\begin{array}{c}\chi^{2}=16,418, \mathrm{df}=1, \mathrm{p}< \\
0,05\end{array}$ \\
\hline $\begin{array}{l}\text { Another person had sexual } \\
\text { intercourse with you } *\end{array}$ & $\begin{array}{c}\mathrm{n}=62 \\
(18,8 \%)\end{array}$ & $\begin{array}{c}\mathrm{n}=100 \\
(27,9 \%)\end{array}$ & $\begin{array}{c}\chi^{2}=7,861, \mathrm{df}=1, \mathrm{p}< \\
0,05\end{array}$ \\
\hline $\begin{array}{l}\text { Another person performed oral } \\
\text { sex on you } *\end{array}$ & $\begin{array}{c}\mathrm{n}=54 \\
(16,4 \%)\end{array}$ & $\begin{array}{c}\mathrm{n}=83 \\
(23,4 \%)\end{array}$ & $\begin{array}{c}\chi^{2}=5,260, \mathrm{df} \\
0,05\end{array}$ \\
\hline $\begin{array}{l}\text { You performed oral sex on } \\
\text { another person }\end{array}$ & $\begin{array}{c}\mathrm{n}=52 \\
(15,9 \%)\end{array}$ & $\begin{array}{c}\mathrm{n}=57 \\
(16,1 \%)\end{array}$ & $\chi^{2}=0,005, \mathrm{df}=1, \mathrm{p}<$ \\
\hline $\begin{array}{l}\text { Someone told you to engage in } \\
\text { sexual activity so that he/she } \\
\text { could watch }\end{array}$ & $\begin{array}{c}\mathrm{n}=11 \\
(3,4 \%)\end{array}$ & $\begin{array}{c}\mathrm{n}=20 \\
(5,8 \%)\end{array}$ & $\begin{array}{c}\chi^{2}=2.259, \mathrm{df} \\
0,05\end{array}$ \\
\hline $\begin{array}{l}\text { You engaged in anal sex with } \\
\text { another person * }\end{array}$ & $\begin{array}{l}\mathrm{n}=11 \\
(3,4 \%)\end{array}$ & $\begin{array}{l}\mathrm{n}=28 \\
(8,1 \%)\end{array}$ & $\begin{array}{c}\chi^{2}=6.735, \mathrm{df} \\
0,05\end{array}$ \\
\hline
\end{tabular}

Significant, $* \mathrm{p}<0,05$

The types of unwanted sexual experiences were classified as "another person showed his or her sex organs to you", "you showed your sex organs to another at his/her request", "someone touched or fondled your sex organs" and "you touched or fondled another person's sex organs at his/her request", amongst others, as illustrated in Table 1. Significantly more Belgian students $(74,2 \%)$ than South African students (66,2\%) reported the incidence of "another person showed his or her sex organs to you" ( $p<0.05)$. Furthermore, South African students were significantly more likely than Belgians students to report the incidence of "someone touched or fondled your sex organs", "you touched or fondled another person's sex organs at his/her request", "another person had sexual intercourse with you", "another person performed oral sex on you" and "you engaged in anal sex with another person" ( $p<0.05)$.

Of the South Africans, 68,3\% of the males and $63,6 \%$ of the females were exposed to exhibiotnism ("another person showed his or her sex organs to you") compared to 75,2\% of the Belgian males and 73,6\% of the Belgian females. Of South African male students, 30,1\% "had 
shown their sex organs to someone at that person's request" compared to $23,1 \%$ of South African female students. When compared to the Belgians, $40 \%$ Belgian male students and $26,3 \%$ Belgian female students fell within the abovementioned category. Of the South African male respondents who had encountered an unwanted sexual experience, 55,2\% reported they "touched or fondled another person's sex organs at that person's request" (vs 49,6\% of the Belgian male respondents). Of the South African female respondents, 63,9\% of them indicated they "touched or fondled another person's sex organs at that person's request" ( $v s 52,3 \%$ of the Belgian female respondents).

Of the Belgian females, 19,5\% reported incidents of sexual intercourse (vs 17,8\% of the South African females). More South African males reported incidents of sexual intercourse compared to their Belgian male counterparts (35,9\% vs 20,5\%). Of South African male students, $24,1 \%$ indicated that "another person had performed oral sex on you" compared to $18,6 \%$ of Belgian male students. More South African females reported incidents of oral sex being performed on them than Belgian females (22,2\% vs 15,2\%). Of South African males, $19 \%$ "performed oral sex on another person" compared to $16,4 \%$ of Belgian males. Slightly more Belgian females reported incidents of "performing oral sex on another person" compared to South African females (15,6\% vs 13\%). "Engaging in sexual activity so that someone could watch" was slightly higher for both South African males (6,7\% vs 5,2\%) as well as for South African females $(4,5 \%$ vs 2,4\%) compared to their Belgian counterparts. Of South African male respondents, 12,1\% reported "engaging in anal sex with another person" compared to 4,4\% of Belgian male respondents, and $4,5 \%$ of South African female respondents, and 2,9\% of Belgian female respondents reported this.

\section{The frequency of coercive events}

Of all the respondents, $66 \%$ of Belgians and 59\% of South Africans indicated that the unwanted sexual experience only happened once; $14 \%$ of both the Belgian and the South African subjects reported that the event occurred twice; and $8 \%$ of the Belgians and 12,5\% of the South Africans reported that the incident happened three to four times. Of the Belgians, $11 \%$ stated that the unwanted sexual experience happened more than five times compared to $13,6 \%$ of South Africans.

Of the Belgian students, $10,7 \%$ reported that the experience lasted up to a month or less compared to $15,5 \%$ of their South African counterparts. Of the Belgians, 12,7\% reported that these experiences happened over a period of several months compared to $13,1 \%$ of the South Africans. Of the Belgian respondents, $10,1 \%$ reported that the experience occurred over a period of one year or longer compared to $9,3 \%$ of the South Africans.

TABLE 2

PERCENTAGE OF STUDENTS REPORTING UNWANTED SEXUAL EXPERIENCES BY VICTIM-PERPETRATOR RELATIONSHIP

\begin{tabular}{|l|c|c|c|}
\hline & & $\begin{array}{c}\text { Belgium } \\
\mathrm{n}(\%)\end{array}$ & $\begin{array}{c}\text { South Africa } \\
\mathrm{n}(\%)\end{array}$ \\
\hline Relative & & $43(14.4)$ & $57(16,4)$. \\
\hline Friend/Acquaintance & & $181(60.6)$ & $251(71,9)$ \\
\hline Stranger & & $75(25)$ & $41(11,7)$ \\
\hline Total & & $299(100)$ & $349(100)$ \\
\hline
\end{tabular}

$\chi^{2}=19,526, \mathrm{df}=2, \mathrm{p}<0,05$ 
The victim-perpetrator relationship

Most respondents indicated that the person involved in the unwanted experience was known to them $(88,2 \%$ of South Africans vs $74,9 \%$ Belgians). More than twice as many Belgian respondents reported that a stranger was involved in the unwanted sexual experience than South African respondents $(25,1 \%$ vs $11,7 \%)$.

The extent to which respondents were bothered by the unwanted sexual experience when it occurred

Table 3 shows that $43,6 \%$ of the Belgian students and $41,4 \%$ of the South African students reported "not being bothered at all" by the experience at the time of the occurrence. Significantly more South African students were "extremely bothered" at the time the event occurred, which reflects the higher incidence of their more severe unwanted sexual experiences.

\section{TABLE 3}

PERCENTAGE OF STUDENTS REPORTING UNWANTED SEXUAL EXPERIENCES BY DEGREE OF BOTHERSOMENESS WHEN IT OCCURRED

\begin{tabular}{|l|c|c|}
\hline & $\begin{array}{c}\text { Belgium } \\
\mathrm{n}(\%)\end{array}$ & $\begin{array}{c}\text { South Africa } \\
\mathrm{n}(\%)\end{array}$ \\
\hline Not bothered at all & $129(43,6)$ & $143(41,4)$ \\
\hline Moderately bothered & $121(40,9)$ & $114(32,9)$ \\
\hline Extremely bothered & $46(15,5)$ & $89(25,7)$ \\
\hline Total & $296(100)$ & $346(100)$ \\
\hline
\end{tabular}

$\chi^{2}=10,797, \mathrm{df}=2, \mathrm{p}<0,05$

Almost twice as many women $(23 \%)$ as men $(12,7 \%)$ were "moderately bothered" by the experience at the time the event occurred and more than five times as many women as men were "extremely bothered" at the time the unwanted experience occurred (17,9\% vs 3,2\%).

The extent to which respondents were bothered by the event when completing the checklist

\section{TABLE 4 \\ PERCENTAGE OF STUDENTS REPORTING UNWANTED SEXUAL EXPERIENCES BY DEGREE OF BOTHERSOMENESS WHEN COMPLETING THE CHECKLIST}

\begin{tabular}{|l|c|c|}
\hline & $\begin{array}{c}\text { Belgium } \\
\mathbf{n}(\boldsymbol{\%})\end{array}$ & $\begin{array}{c}\text { South Africa } \\
\mathbf{n}(\boldsymbol{\%})\end{array}$ \\
\hline Not bothered at all & $211(71,5)$ & $209(60,6)$ \\
\hline Moderately bothered & $62(21)$ & $77(22,3)$ \\
\hline Extremely bothered & $22(7,5)$ & $59(17,1)$ \\
\hline Total & $295(100)$ & $345(100)$ \\
\hline
\end{tabular}

$\chi^{2}=14,713, \mathrm{df}=2, \mathrm{p}<0,05$

Of Belgian students, $71,5 \%$ were "not bothered at all" by the unwanted sexual experience at the time of completing the ESEC compared to $60,6 \%$ of South African students. More then twice as many South Africans $(17,1 \%)$ than Belgians $(7,5 \%)$ were "extremely bothered" by the incident at the time of completing the ESEC. Of the men respondents, $16 \%$ were "moderately bothered" by the unwanted sexual experience at time of completing the ESEC as were 24,9\% 
of the women respondents. Of the men respondents, 9,6\% were "extremely bothered" by the unwanted sexual experience at the time of completing the ESEC as were $15 \%$ of the women.

\section{DEGREE OF SEXUAL COERCION}

The kinds of psychological pressures that were brought to bear on the respondents were as follows: $21 \%$ of the South African and 9,3\% of the Belgian students stated that the other person tried to talk them into it. Of the South Africans, 8,8\% were scared of the other person because he or she was bigger or stronger compared to $4,4 \%$ of the Belgian respondents. Less than $1,5 \%$ of Belgian and $4 \%$ of South African respondents stated that the other person threatened to hurt them. Bribery, being pushed, hit or physically restrained ranged between 3 $1 \%$ for the Belgians and 4,2-6,2\% for the South Africans. Of the South African respondents, $9 \%$ reported being afraid of not being liked or loved by the other person compared to $3,4 \%$ of Belgian respondents. Of the Belgians, 3,4\% reported being drugged or made drunk compared to $1,4 \%$ of the South African students. Less than $2 \%$ of the South Africans and Belgians were physically harmed or injured and $2 \%$ of the South Africans were threatened with a weapon, while none of the Belgians indicated such a threat. Generalization from these findings should be done cautiously, because our samples were drawn from first-year students and from only two universities.

\section{DISCUSSION}

South African students' exposure to unwanted sexual experiences (39\%) compared to their Belgian counterparts $(13,5 \%)$ endorses the view of South Africa as a high-CSA incidence country. The study, however, highlighted that Belgian students reported higher prevalence of non-contact types of unwanted sexual experiences when compared to their South African counterparts. This study highlighted the significantly higher prevalence of South African students reporting unwanted sexual experiences involving a family member or a friend/acquaintance compared to the Belgian students. These findings have important implications for primary prevention, such as the notion of "stranger danger" (Collings, 1997).

This study indicated that more than half of the students were bothered by the unwanted sexual experience at the time it occurred. A smaller proportion (28\% to $38 \%)$ of students was bothered by the unwanted event at the time of completing the checklist. Possible reasons for the decrease in the bothersomeness of the unwanted event could be the fact that most of the students reported a once-off occurrence. Additionally the recall period could also have an effect on the decrease of the bothersomeness of the unwanted sexual experience.

While no Belgian respondents reported being threatened with a weapon during the unwanted sexual experience, $2 \%$ of South Africans reported such an occurrence. Conversely, more than double the number of Belgian respondents reported being drugged or made drunk during the unwanted sexual experience compared to South Africans.

Oaksford and Frude (2001) urged researchers to focus on homogeneous samples using a larger sample sizes of both clinical and non-clinical participants. The current study sample therefore provides valuable information about the prevalence and nature of unwanted sexual experiences within a population that seems to be coping with the demands of tertiary education. The prevalence and sequelae of unwanted childhood sexual experiences are a neglected issue for university students that thus requires greater attention from university-based counsellors. 


\section{REFERENCES}

BACK, S.E., JACKSON, J.L., FITZGERALD, M., SHAFFER, A., SALSTROM, S. \& OSMAN, M.M. 2003. Child sexual and physical abuse among college students in Singapore and the United States. Child Abuse and Neglect, 27(11):1259-1275.

COLLINGS, S.J. 1997. Child sexual abuse in a sample of South African women students: Prevalence, characteristics and long-term effects. South African Journal of Psychology, 27(1):37-42.

DAVIS, C.M., YARBER, W.L., BAUSERMAN, R., SCHREER, G. \& DAVIS, S.L. 1998. Handbook of Sexuality-Related Measures. London: Sage Publications.

FINKELHOR, D. 1994. The international epidemiology of child sexual abuse. Child Abuse and Neglect, 18(5):409-417.

JEWKES, R. 2002. South Africa: Teachers raping school girls. Women's International Network News Autumn, 28(4):61.

KENDALL-TACKETT, K.A., WILLIAMS, L.M. \& FINKELHOR, D. 1993. Impact of sexual abuse on children: A review and synthesis of recent empirical studies. Psychological Bulletin, 113:164-180.

MADU, S.N. 2001. The prevalence and patterns of childhood sexual abuse and victimperpetrator relationship among a sample of university students. South African Journal of Psychology, 31(4):32-38.

MADU, S. \& PELTZER, K. 2000. Risk Factors and child sexual abuse among secondary school students in the Northern Province (South Africa). Child Abuse and Neglect, 24(2):259-268.

MEIER, E. 2002. Child rape in South Africa. Pediatric Nursing, 28(5):532-535.

MILLER, R.S. \& JOHNSON, J. 1998. Early sexual experiences cheklist. In: DAVIS, C.M., YARBER, W.L., BAUSERMAN, R., SCHREER, G. \& DAVIS, S.L. (ed) Handbook of sexuality-related measures. London: Sage Publications.

MILLER, R.S., JOHNSON, J.A. \& JOHNSON, J.K. 1991. Assessing the prevalence of unwanted childhood sexual experiences. Journal of Psychology and Human Sexuality, 4:4354.

NAJMAN, J.M., DUNNE, M.P., PURDIE, D.M., BOYLE, F.M. \& COXETER, P.D., 2005. Sexual abuse in childhood and sexual dysfunction in adulthood: An Australian populationbased study. Archives of Sexual Behavior, 34(5):517-526.

OAKSFORD, K.L. \& FRUDE, N. 2001. The prevalence and nature of child sexual abuse: Evidence from a female university sample in the UK. Child Abuse Review, (10):49-59.

RIND, B., TROMOVITCH, P. \& BAUSERMAN, R. 1998. A meta-analytic examination of assumed properties of child sexual abuse using college samples. Psychological Bulletin, 124(1):22-53.

WOMEN'S INTERNATIONAL NETWORK NEWS (WIN). 2002. South Africa's alarming increase in the rapes of children, cited in The New York Times, Spring: 68.

Ms Arlynn Tracy Revell and Prof Alfons Vansteenwegen, Instituut voor Familiale en Seksuologische Wetenschappen, Faculteit Geneeskunde, Katholieke Universiteit Leuven, Belgium and Prof Lionel John Nicholas, Department of Psychology, University of Fort Hare, South Africa. 